\title{
Prevalence of Plasmodium Species Infection Among Private Security Guards in Kaduna Metropolis, Kaduna State-Nigeria
}

\author{
Victor Oluwasanmi Amusan", Yahaya Abdullahi Umar, Philip Anthony Vantsawa \\ Department of Biological Sciences, Nigerian Defence Academy, Kaduna, Nigeria
}

Email address:

voaplus@yahoo.com (V. O. Amusan)

${ }^{*}$ Corresponding author

\section{To cite this article:}

Victor Oluwasanmi Amusan, Yahaya Abdullahi Umar, Philip Anthony Vantsawa. Prevalence of Plasmodium Species Infection Among Private Security Guards in Kaduna Metropolis, Kaduna State-Nigeria. European Journal of Clinical and Biomedical Sciences.

Vol. 3, No. 2, 2017, pp. 43-46. doi: 10.11648/j.ejcbs.20170302.11

Received: February 5, 2017; Accepted: February 20, 2017; Published: March 21, 2017

\begin{abstract}
Private security guards play an important role in providing security to the citizenry especially in a developing country like Nigeria. They are however many at times exposed to vector borne diseases such as malaria. To determine the prevalence of Plasmodium species infections among private security guards in Kaduna metropolis, Kaduna-Nigeria, two hundred and sixty-one (261) blood samples were collected and screened for malaria parasite using Malaria Ag P.f and Malaria Ag P.f/Pan kits (SD BIOLINE, Cat. No: SD05FK50 and SD05FK60 respectively). Demography information on guards were collected using structured questionnaires. Result obtained showed an overall prevalence of 17.62\% Plasmodium infection among guards screened using both kits. Age, sex and season were found to significantly influence the prevalence of $P$. falciparum infection among guards in Kaduna metropolis $(\mathrm{P}<0.05)$. It is recommended that managements of private security outfits should provide their staff with adequate protective measures against mosquito transmitted diseases for improved workers efficiency and reduce man hour loss.
\end{abstract}

Keywords: Prevalence, Malaria, Plasmodium Species, Guards

\section{Introduction}

Malaria caused by Plasmodium species is the most common protozoan parasitic disease in the tropical and subtropical regions of the world and is transmitted to man through the bites of infected female anopheline mosquito [1, 2, 3]. Plasmodium falciparum, $P$. ovale, $P$. vivax, and $P$. malariae are reported to cause disease in man in different parts of the world [4]. However, infections due to $P$. falciparum is the most common and deadly [5].

Malaria is a major public health problem with over 3.2 billion of the world's population at risk and an estimated global mortality rates of $42 \%$ since $2000[6,7]$. Of these deaths, Africa accounts more than $80 \%$ with most cases occurring in Democratic Republic of Congo and Nigeria [8].

In Nigeria morbidity and mortality due to malaria has enormous consequences on the economy. It is a major cause of increased man hour loss, increased rate of absenteeism, low performance among primary school children and workers including security guards. Transmission of malaria among different populations temporarily outside the home due to occupational and recreational reasons play a significant role in the epidemiology of malaria.

In the words of the commander in chief of British forces in Burma during World War II, Field Marshal Viscount Sir Archibald Wavell, "We must be prepared to meet malaria by training as strict and earnest as that against enemy troops. We must be as practiced in our weapons against it as we are with a rifle". This statement underlines the reality that losses to malaria and other preventable diseases far exceeded the number of casualties inflicted by enemy action [9].

The present study is aimed at determining the prevalence of $P$. falciparum infection among private security guards in Kaduna metropolis, Nigeria. This is to provide information to relevant government agencies involved in the control of malaria, and managers of private security outfits to take appropriate policy decision for maximum efficiency. 


\section{Materials and Methods}

\subsection{Study Area}

Kaduna metropolis is the capital of Kaduna State and is located in the North-West geopolitical zone of Nigeria. It lies between latitude $10^{\circ} 20^{\prime} \mathrm{N}$ and $10.33^{\circ} \mathrm{N}$, and longitude $7^{\circ} 45^{\prime} \mathrm{E}$ and $7.75^{\circ} \mathrm{E}$. The state shares borders with Kano, Katsina and Zamfara states to the North, Plateau and Bauchi states to the East, Nasarawa state and the Federal Capital Territory (FCT) to the South and Niger state to the West [10]. Kaduna State have distinct dry and wet seasons and is characterised by Guinea savannah type of vegetation [11].

\subsection{Study Population/Sample Size}

The study population was made up of 234 male and 27 female private security guards keeping watch on private and public properties in Kaduna Metropolis, Nigeria and have consented to participate in the study.

\subsection{Ethical Permission}

Approval to conduct the study was obtained from the Kaduna State Ministry of Health Ethical Committee before sample collection commenced among the guards. Code of ethics on the use of human subjects in research as outlined in the NDA Research and Development Policy, 2016 was also adhere to strictly.

\subsection{Blood Collection and Screening}

Screening for malaria parasite was done using SD BIOLINE Malaria Ag P.f and SD BIOLINE Malaria Ag P.f/Pan kit (Standard Diagnostics, Inc., Republic of Korea. Cat. No: SD05FK50 and SD05FK60 respectively) adhering to manufacturer's guide. Fingertips of individual guards was cleaned thoroughly with alcohol swap and pricked with a sterile lancet. Using $5 \mu$ l capillary pipette provided with the kits, blood was drawn by capillary action to a black line and carefully transferred into a sample well on the kit and pressed gently. To the diluent well, 4 drops of assay diluent (buffer) provided with the kit was added, allowed to stand for $15 \mathrm{~min}$ and result was read.

\subsection{Questionnaire Administration}

Structured questionnaire was administered to obtain information on the demographic characteristics of respondents. Each questionnaire was assigned a code to enable tracking of respondents.

\subsection{Statistical Analysis}

Data was processed using EpiData version 3.1 and each dataset subsequently exported to SPSS version 20 for analysis. Datasets were analysed and interpreted using descriptive statistics. Chi-Square test was used to test association between risk factors and Plasmodium falciparum infection. Five $(5 \%)$ level of probability was considered significant $(\mathrm{P}<0.05)$.

\section{Result}

Out of the 261 security guards screened for $P$. falciparum infection, $46(17.62 \%)$ were found to be positive using either of the Malaria immunodiagnostic kits (Table 1). However, male guards recorded significantly higher prevalence $(18.38 \%)$ than female guards who recorded $11.11 \%(\mathrm{P}<$ 0.05 ) (Table 2).

Table 1. Overall prevalence of Plasmodium falciparum infection among private security guards in Kaduna metropolis, Nigeria.

\begin{tabular}{llll}
\hline $\begin{array}{l}\text { Diagnostic } \\
\text { Kit }\end{array}$ & $\begin{array}{l}\text { Number of } \\
\text { Individuals } \\
\text { Examined }\end{array}$ & $\begin{array}{l}\text { Number of } \\
\text { Individuals } \\
\text { Positive }\end{array}$ & $\begin{array}{l}\text { Percentage (\%) } \\
\text { Positive }\end{array}$ \\
\hline P.f & 261 & 46 & 17.62 \\
P.f/Pan & 261 & 46 & 17.62 \\
\hline
\end{tabular}

Table 2. Prevalence of Plasmodium falciparum infection among private security guards in relation to sex.

\begin{tabular}{llll}
\hline Sex & $\begin{array}{l}\text { Number of } \\
\text { Individuals } \\
\text { Examined }\end{array}$ & $\begin{array}{l}\text { Number of } \\
\text { Individuals } \\
\text { Positive }\end{array}$ & $\begin{array}{l}\text { Percentage } \\
\text { (\%) Positive }\end{array}$ \\
\hline Male & 234 & 43 & 18.38 \\
Female & 27 & 03 & 11.11 \\
Total & 261 & 46 & 17.62 \\
\hline
\end{tabular}

$\mathrm{X}^{2}=34.783 ; \mathrm{DF}=1 ; \mathrm{P}=0.000$

Prevalence of Plasmodium infection was found to be significantly influenced by age of guards surveyed $(\mathrm{P}<0.05)$. Guards aged 41-50 yrs recorded the highest prevalence of $P$. falciparum infection $(26.32 \%)$, followed by guards within 51-60, 21-30 and 31-40 yrs age groups with prevalence rates of $18.92 \%, 16.87 \%$ and $14.52 \%$ respectively. However, guards aged 15-20 yrs showed no evidence of $P$. falciparum using both Malaria Ag P.f and Malaria Ag P.f/Pan kits (Table 3).

The seasonal prevalence of Plasmodium infection among private security guards survey in Kaduna metropolis is presented in Table 4. Out of the 130 security guards screened during the dry season, $34(26.15 \%)$ were found to be positive for $P$. falciparum infection. However, significantly lower cases of $P$. falciparum infection were detected during wet season $(9.16 \%)(\mathrm{P}<0.05)$.

Table 3. Prevalence of Plasmodium falciparum infection among private security guards in relation to age.

\begin{tabular}{llll}
\hline Age (Yrs) & $\begin{array}{l}\text { Number of } \\
\text { Individuals } \\
\text { Examined }\end{array}$ & $\begin{array}{l}\text { Number of } \\
\text { Individuals } \\
\text { Positive }\end{array}$ & $\begin{array}{l}\text { Percentage } \\
\text { (\%) Positive }\end{array}$ \\
\hline $15-20$ & 09 & 00 & 00 \\
$21-30$ & 83 & 14 & 16.87 \\
$31-40$ & 62 & 09 & 14.52 \\
$41-50$ & 57 & 15 & 26.32 \\
$51-60$ & 37 & 07 & 18.92 \\
Above 60 & 13 & 01 & 07.69 \\
Total & 261 & 46 & 17.62 \\
\hline
\end{tabular}

$\mathrm{X}^{2}=14.000 ; \mathrm{DF}=4 ; \mathrm{P}=0.007$ 
Table 4. Seasonal prevalence of Plasmodium falciparum infection among private security guards.

\begin{tabular}{llll}
\hline Season & $\begin{array}{l}\text { Number of } \\
\text { Individuals } \\
\text { Examined }\end{array}$ & $\begin{array}{l}\text { Number of } \\
\text { Individuals } \\
\text { Positive }\end{array}$ & $\begin{array}{l}\text { Percentage (\%) } \\
\text { Positive }\end{array}$ \\
\hline Dry & 130 & 34 & 26.15 \\
Wet & 131 & 12 & 9.16 \\
Total & 261 & 46 & 17.62 \\
\hline
\end{tabular}

$\mathrm{X}^{2}=10.522 ; \mathrm{DF}=1 ; \mathrm{P}$-value $=0.001$
Similarly, level of educational attainment is found to significantly influence the prevalence of $P$. falciparum infection among the guards $(\mathrm{P}<0.05)$ (Table 5). Security guards with no formal education recorded the highest prevalence $(25 \%)$, followed by guards who have completed primary school (23.4\%), secondary school dropouts $(23.08 \%)$ and post-secondary school (16.67\%). Graduate guards (Degree and above) recorded no case of $P$. falciparum infection.

Table 5. Prevalence of Plasmodium falciparum infection among private security guards in relation to level of education.

\begin{tabular}{llll}
\hline Education & Number of Individuals Examined & Number of Individuals Positive & Percentage (\%) Positive \\
\hline No formal schooling & 16 & 04 \\
Primary school dropouts & 10 & 01 \\
Complete primary school & 47 & 11 \\
Secondary school dropouts & 13 & 03 \\
Complete secondary school & 124 & 20 & 10.00 \\
Post-secondary & 42 & 07 & 23.40 \\
Degree and above & 09 & 00 & 23.08 \\
Total & 261 & 46 & 16.13 \\
\hline
\end{tabular}

$\mathrm{X}^{2}=31.739 ; \mathrm{DF}=5 ; \mathrm{P}=0.000$

\section{Discussion}

Malaria parasite prevalence studies among security guards are rare in Nigeria, but ample among other population. The overall prevalence of $17.62 \%$ reported in this study was quite low. Previous studies among other population by [12] reported a prevalence of $14.7 \%$ while a prevalence of $35.7 \%$ was reported by [11]. This study revealed that $P$. falciparum infection prevalence was higher among the men (18.38\%) than the women $(11.11 \%)$ although more male participants were screened, the males had a higher prevalence of the disease which was statistically significant; this suggests that males may be more prone to the disease than females.

The highest prevalence was recorded within the age group of 41-50 years $(26.32 \%)$ while the age group of $15-20$ years have no $P$. falciparum infection prevalence and this could probably be associated with their immunological factor [13, 14]. As observed, the high prevalence rate of $P$. falciparum infection prevalence among higher age group may have been attributed to premunition which is a state of balance between host and infectious agent, as a parasite, such that the immune defence of the host is sufficient to resist further infection but insufficient to destroy the agent. When such individuals are screened, parasite detection is possible.

The seasonal prevalence for dry and wet season were $26.15 \%$ and $9.16 \%$ respectively. Factors that determine malaria incidence are diverse and complex but it is known that the environment plays an important role in the transmission of infectious diseases. The environmental factors that affect the distribution and incidence of malaria are rainfall, temperature and humidity $[15,16,17]$. The low incidence noted throughout the wet season in this study is reinforced by similar resolutions of various researchers alike who found that malaria occurrence is usually absent or low during rainy season. During heavy rainfall, the water flow washes out the pools and other mosquito breeding places [18, 19]. In Tanzania, [20] connected rainfall with low incidence of malaria. It was suggested also by [21] that the suitability of vectors habitat is determined by the minimum precipitation level. Ponds dug to counter water problem in living areas that experience difficulty with water during the dry season can become new mosquito breeding site. Irrigated water can also serve as mosquito breeding site and further lessen their dependency on rainfall and this is one of the possible factors that can explain why the malaria incidence can still increase during the dry season.

In relation to level of education, the group of guards with no formal education have the highest prevalence $(25 \%)$ while the group with university degrees or equivalent qualifications have no prevalence, and this suggests that the group with highest level of education put their wealth of knowledge and experience to prevent malaria parasite prevalence and due to the security outfit organogram, this group is the least exposed and only does supervisory duties.

The predominant Plasmodium spp. identified in this study was $P$. falciparum, which is the most virulent and also has the greatest tendency for developing resistance [22], these findings are consistent with other reported studies $[11,12$, 23].

\section{Conclusion}

Prevalence of $P$. falciparum infection is relatively low compared to reports by other authors in other parts of Nigeria. However, it may play a significant role in reducing work output of security guards in the study area considering the complications associated with falciparum malaria. In addition, malaria Ag P.f and malaria Ag P.f/Pan lateral flow immunochromatographic antigen detection kits are both effective in detection of $P$. falciparum infection. 


\section{Recommendations}

Management of private security outfits in Kaduna State should provide guards with personal protective measures against vector borne diseases such as malaria coupled with regular screening of guards to enable early treatment for maximum productivity. Malaria Ag P.f immunochromatographic test kit could be used as substitute to malaria Ag P.f/Pan test kit for detection of $P$. falciparum infection to save cost.

\section{References}

[1] WHO. (2006). Malaria vector control and personal protection: report of a WHO study group.

[2] Olumese, P. E., Gbadegesin, R. A., Adeyemo, A. A., Brown, B., and Walker, A. (1999). Neurological features of cerebral malaria in Nigerian children. Annals of Tropical Paediatrics: International Child Health, 19 (4): 321-325.

[3] Krief, S., Escalante, A. A., Pacheco, M. A., Mugisha, L., André, C., Halbwax, M., and Cornejo, O. E. (2010). On the diversity of malaria parasites in African apes and the origin of Plasmodium falciparum from Bonobos. PLoS Pathogen, 6 (2).

[4] Nonstrand, V. (1978). Malaria in Scientific Encyclopedia (6th ed.). Van Nonstrand Reinhold Company, New York, pp. 18121813 .

[5] Miller, S. A. and Marley, J. P. (1999). Zoology 4th Edition. WMC Brown Publishers, Debuque Lowa Melbourne, Australia. pp. 251-253.

[6] White NJ, Pukrittayakamee S, Hien TT, Faiz MA, Mokuolu OA, Dondorp AM. (2014). Malaria. Lancet, 383: 723-35.

[7] WHO. (2014): World Malaria Report 2014. Geneva, World Health Organization, 2014.

[8] WHO. (2013). World Health Organization, World Malaria Report 2013: Summary And Key Points, World Health Organization, 2013.

[9] Smith, A. M., and Hooper, C. (2016). The mosquito can be more dangerous than the mortar round-the obligations of command. Journal of Military and Veterans Health, 24 (3): 60.

[10] Mohammed, M., Vantsawa, P. A, Abdullahi, U. Y. and Muktar, M. D. (2015). Nutritional Status and Prevalence of Intestinal Schistosomiasis among Al-majiri Population in Kawo District of Kaduna Metropolis, Kaduna State-Nigeria. Journal of Bacteriology and Parasitology, 6: 237-242.

[11] Umaru, M. L., and Uyaiabasi, G. N. (2015). Prevalence of Malaria in Patients Attending the General Hospital Makarfi,
Makarfi Kaduna-State, North-Western Nigeria. American Journal of Infectious Diseases and Microbiology, 3 (1): 1-5.

[12] Aina, O. O., Agomo, C. O., Olukosi, Y. A., Okoh, H. I., Iwalokun, B. A., Egbuna, K. N.,... and Akinyele, M. O. (2013). Malariometric survey of Ibeshe community in Ikorodu, Lagos state: dry season. Malaria Research and Treatment, 2013.

[13] Chatterjee, K. D. (2009). Parasitology: Protozoology and Helminthology. (13th Edn.). CBS Publishers and Distributors Private Limited. New Delhi, India. pp 90-137.

[14] Paniker, C. K. J. (2007). Medical Parasitology. (6th edn.). Jaypee Brothers Medical Publishers (P) Ltd, New Delhi, India. pp 65-95.

[15] MARA. (1998). Towards an Atlas of Malaria Risk in Africa. First Technical Report of the MARA/ARMA Collaboration, Durban, MARA/ARMA (Mapping Malaria Risk in AFRICA/Atlas du Risque de la Malaria en Afrique).

[16] Sweeney, A. W. (1998). The Application of GIS in Malaria Control Programs. Paper Presented at the 10th Colloquium of the Spatial Information Research Centre, University of Otago, New Zealand.

[17] National Research Council (2001). Under the weather Climate, ecosystems and infectious disease. Washington DC: National Academy Press.

[18] Aron, J. L., and Patz, J. A. (2001). Ecosystem change and public health: a global perspective. The Johns Hopkins University Press: Baltimore, MD: 285-291.

[19] Wijesundera, M. D. S. (1988). Malaria outbreaks in new foci in Sri Lanka. Parasitology Today, 4 (5): 147-150.

[20] Lindsay, S. W., Bødker, R., Malima, R., Msangeni, H. A., and Kisinza, W. (2000). Effect of 1997-98 EI Niño on highland malaria in Tanzania. The Lancet, 355 (9208): 989-990.

[21] Martens, P., Kovats, R. S., Nijhof, S., De Vries, P., Livermore, M. T. J., Bradley, D. J.,... and McMichael, A. J. (1999). Climate change and future populations at risk of malaria. Global Environmental Change, 9: S89-S107.

[22] Happi, C. T., Gbotosho, G. O., Folarin, O. A., Sowunmi, A., Hudson, T., O'Neil, M., and Oduola, A. M. J. (2009). Selection of Plasmodium falciparum multidrug resistance gene 1 alleles in asexual stages and gametocytes by artemether-lumefantrine in Nigerian children with uncomplicated falciparum malaria. Antimicrobial Agents and Chemotherapy, 53 (3): 888-89.

[23] Noland, G. S., Graves, P. M., Sallau, A., Eigege, A., Emukah, E., Patterson, A. E., and Alphonsus, K. (2014). Malaria prevalence, anemia and baseline intervention coverage prior to mass net distributions in Abia and Plateau States, Nigeria. BMC Infectious Diseases, 14 (1): 1. 